Revue Française de Civilisation Britannique

\title{
Brexit, Indyref2 and the 2019 General Election in Scotland
}

Le Brexit et indépendance de l'Ecosse aux élections législatives de 2019

\section{Fiona Simpkins}

\section{(2) OpenEdition}

\section{Journals}

Electronic version

URL: http://journals.openedition.org/rfcb/5802

DOI: $10.4000 /$ rfcb.5802

ISSN: 2429-4373

\section{Publisher}

CRECIB - Centre de recherche et d'études en civilisation britannique

Electronic reference

Fiona Simpkins, « Brexit, Indyref2 and the 2019 General Election in Scotland », Revue Française de Civilisation Britannique [Online], XXV-3 | 2020, Online since 10 September 2020, connection on 10 September 2020. URL : http://journals.openedition.org/rfcb/5802 ; DOI : https://doi.org/10.4000/rfcb. 5802

This text was automatically generated on 10 September 2020 .

Revue française de civilisation britannique est mis à disposition selon les termes de la licence Creative Commons Attribution - Pas d'Utilisation Commerciale - Pas de Modification 4.0 International. 


\title{
Brexit, Indyref2 and the 2019 General Election in Scotland
}

\author{
Le Brexit et indépendance de l'Ecosse aux élections législatives de 2019
}

\author{
Fiona Simpkins
}

\section{Introduction}

1 The slim Conservative majority which Boris Johnson inherited from Theresa May after she resigned from office in July 2019 did not survive long under the new Prime Minister. It soon became apparent that his first few months in office were veered towards a new general election and that his campaign had started the day he settled in 10 Downing Street. The only way to change the arithmetic in the House of Commons was to force a new election and take a united stand on the Brexit issue in order to gain a majority of Conservative MPs. Theresa May's downfall, like that of three of her predecessors, had been caused by constant infighting over Europe in her party and she had been unable to secure a majority for the agreement she struck with her European counterparts. Boris Johnson's brutal purge of Conservative Cabinet ministers and 21 Conservative MPs who had voted against him on Brexit were a sign that he expected his troops to line behind him as he prepared for a new electoral battle. The objective was to argue that his party was the only one able to break the impasse among politicians at Westminster and "get Brexit done" to move the country forward. The Conservative campaign was therefore light on policy detail but relied instead on strict discipline and a core Brexit message meant to woo Brexit supporters of all colours and specifically court Labour leave voters of the North and Midlands. The demographics of the 2016 European referendum having shown that many Leave voters were to be found among the ranks of traditional Labour voters, Johnson and his advisers wanted to strike directly at Labour's heartlands in the hope that Brexit would trump traditional party allegiances.

2 Their strategy eventually produced a commanding majority of 365 seats in the House of Commons: the Conservatives managed to win seats such as Bishop Auckland and 
Sedgefield, which had voted Labour for generations but had returned Leave majorities in the 2016 European referendum. However, it was clear that a similar strategy was never going to function in Scotland where 62\% voted Remain in 2016. Neither could the Conservatives afford to ignore Scotland as they knew too well that they had only managed to snatch victory out of the jaws of defeat in the 2017 general election thanks to the crucial addition of thirteen Scottish Conservative seats. The upsurge in Conservative votes in Scotland under the leadership of Ruth Davidson coincided with a strong unionist message which had proved fruitful in the 2017 general election despite a political context dominated by Brexit. However, the Scottish Conservatives' charismatic and outspoken pro-Remain leader, Ruth Davidson, resigned in August 2019 and the party was led by a more lacklustre acting leader, Jackson Carlaw, as it entered the 2019 general election campaign. Could the Scottish Conservatives repeat their success of 2017 by focusing on the Union and betting that Scotland's constitutional debate would once again trump the issue of Brexit? This paper will seek to compare the last two general election campaigns in Scotland in order to determine to what extent Brexit determined the results of the 2019 general election.

\section{The 2019 general election results in Scotland: swinging back to the SNP}

The stark difference between the last two general elections is immediately noticeable on Scotland's electoral map: the 2019 general election marked a return of the SNP as the Nationalists won 48 out of 59 seats, that is 13 seats more than in 2017, but still 8 seats behind their historic high of 2015. There was no "Nationalist tsunami" as in 2015 but the 2019 general election results nonetheless sent a strong message to the majority party in Westminster as the SNP increased their share of the vote to $45 \%$. Whether this was the result of a protest vote over Brexit and Conservative policies or a full-hearted swing to independence, Scottish voters were clearly voicing their opposition to Brexit and Boris Johnson's government by endorsing the SNP's rejection of Brexit and demands for a second independence referendum in a majority of scottish constituencies. The higher turnout to the election would also indicate the heightened perceived importance of the election compared to that of 2017 and suggests that more voters may have considered voting to either express their concerns about or opposition to Brexit and Boris Johnson, or their feelings about Scotland's constitutional issue. Indeed, while lower than the 2015 general election turnout (71.1\%), the 2019 election turnout was almost two points higher than in 2017 (increasing from $66.4 \%$ to $68.1 \%$ ) and almost one point higher than that of the UK as a whole (67.3\%).

The two main unionist parties, Labour and the Conservatives, lost six and seven seats respectively - falling to one single seat for the former and six for the latter - while the Liberal Democrats managed to keep four seats in Scotland with the loss of Dumbartonshire East compensated by the gain of North East Fife. Although Labour managed to cling on to the seat of Edinburgh South which it had already won in 2015, the party's share of the vote was at a historic low of $18.6 \%$, that is 8.5 points below its 2017 score. The Labour party garnered more support in Central Belt constituencies, especially in and around Glasgow where it often came second after the SNP, but fared very poorly in the Borders region, North East as well as Highlands and Islands constituencies. The Conservative performance, albeit better than it was for decades in 
Scotland, was disappointing to the party. Although their share of the vote only dropped by 3.5 points (to $25.1 \%$ ), they were unable to keep more than half of their seats. The loss of their extremely popular pro-Remain leader, Ruth Davidson, in August 2019 and her replacement by a more lacklustre acting leader, Jackson Carlaw, dented their chances of making the most of their strong unionist message.

The unpopularity of Prime Minister Boris Johnson north of the border may also have hurt the Conservative vote: a series of Panelbase polls in November and December 2019 found that $59 \%$ of respondents in Scotland thought he was doing a bad or very bad job as Prime Minister compared to $44 \%$ overall in the UK. Similarly, Labour would have also appeared to suffer from the lack of popularity of its UK leader: while $21 \%$ of Labour voters in Scotland said they backed the Labour party because it had the best leader, only $3 \%$ of them did so in 2019 . More Labour voters (33\%) cited the party's policies as being decisive of their choice in 2019 than in 2017 (26\%), thus implying that they voted for Labour despite its leader rather than because of him. ${ }^{1}$ In contrast, Nicola Sturgeon's popularity undoubtedly served as an asset to the Nationalists, with $51 \%$ of respondents saying that she was doing very well or fairly well as First Minister in a YouGov poll of December 2019 (up from 49\% in April 2017).

6 Nevertheless, while all seven of the lost Conservative seats were won by the SNP, the Conservatives' losses in terms of vote share in these seats were rather low, oscillating between $2.8 \%$ in Ochill \& South Perthshire, 3.5\% in Stirling, 4.9\% in East Renfrewshire and $6.2 \%$ in Aberdeen South for instance. The Conservatives' share of the vote even increased by $0.5 \%$ in Gordon despite their loss of that particular constituency. This would suggest that the Scottish Conservatives did not lose their core support despite the unpopularity of their UK leader, the loss of Ruth Davidson as Scottish leader and her replacement by Jackson Carlaw.

7 The common denominator to all these swing constituencies appears to be a substantial increase of the Nationalists' share of the vote. In Gordon, for instance, the SNP increased its share of the vote by $6.9 \%$ and appears to have benefited from the losses suffered by Labour $(-6.4 \%)$ and the Liberal Democrats (-1\%). In Stirling, the SNP won $14.4 \%$ of votes as Labour lost $14 \%$. Similarly, in the constituency of East Renfrewshire, the SNP gained $13.7 \%$ more votes than in 2017 , while Labour lost $14.3 \%$ and the Conservatives $4.9 \%$. In Ochill \& South Perthshire, the SNP won an extra $11.2 \%$ of votes while Labour lost $11.4 \%$ and the Conservatives $2.8 \%$. This suggests that the SNP was the main recipient for Labour votes and that many Labour voters decided to switch their vote to the SNP to send a message.

\section{The unionist campaigns}

As in the rest of the UK, it would appear that the Scottish Labour Party suffered from Jeremy Corbyn's choice of a neutral stance over Brexit. Although the Labour leader reluctantly allowed his Scottish counterpart, Richard Leonard, to campaign for remain, most voters would have been aware of Jeremy Corbyn's Euroscepticism and plans to broker a fresh Brexit deal with the EU before putting it to a referendum if a Labour government was elected. The Scottish Labour Party's commitment to a pro-remain stance in its electoral manifesto may therefore have been interpreted as a hollow promise and contributed to the apparent confusion and lack of decisiveness demonstrated by the mixed messages and contradictory statements which plagued its 
campaign. Scottish Labour understandably attempted to distance itself from its UK counterpart in order to better adapt to the pro-European Scottish landscape. Although the party had managed to increase its share of the vote by $2.8 \%$ and win six extra seats in the 2017 general election, it was aware that its humiliating defeat in the European parliament elections of May 2019 was due to its leadership's ambiguous position over Brexit. The party's share of the vote dropped to 9.3\% in May 2019 and Labour failed to return an MEP from Scotland for the first time in its history, while the SNP won 3 seats and the Liberal Democrats a further seat on a firm pro-remain stance.

Like its UK counterpart, Scottish Labour attempted to reverse that slump by focusing its campaign on a wide range of generous social policies and spending commitments, unveiling a multi-billion pound pledge to offer all school pupils free meals throughout the year, as well as promising to a £2bn new low-carbon Scotland-wide bus fleet, a £70bn infrastructure fund and an extra £6bn on improving the country's housing stock. Many of its pledges, however, related to issues, such as education or health, which are devolved to the Scottish Parliament. This meant that Labour would either have had to win the support of the Scottish government or win the next Holyrood election in 2021 before it could effectively introduce these policies. Furthermore, if further proof were needed of Scottish Labour's difficulties to prove its Scottish credentials and emancipate itself from the UK Labour party, the Scottish manifesto included several significant concessions to the UK party on both the renewal of the Trident nuclear weapons system, which a vast majority of Scots are opposed to, and the timing of a Scottish independence referendum.

The latter proved to be a thorn in the Scottish leader's side as the Scottish Labour's party policy on the issue so far has been to firmly oppose a second independence referendum and to prove its credentials as a strong defender of the Union. In doing so, it vies to fight with the Conservatives over the unionist majority of Scottish voters but has suffered from the mixed signals that some of its senior figures have sent over the years. Former Scottish leader Kezia Dugdale, for instance, admitted that it wouldn't be "inconceivable" for her to argue against the UK Union in an interview with the Fabian Review of April 2016. Although she retracted her statement immediately, she then claimed in July of the same year that it would be "categorically wrong" for the UK government to block a second independence referendum if it were called for by the Scottish people ${ }^{2}$.

Richard Leonard was in turn embarrassed by the Shadow Chancellor, John McDonnell, in August 2019, after the latter declared that the party accepted a Labour government could not block a Scottish government request for the powers to hold a fresh independence vote. Jeremy Corbyn himself made several contradictory statements over a second independence referendum during the 2019 campaign, initially denying the possibility of holding a second referendum for the entire five years of the next parliament before saying that this position may change if the SNP won the May 2021 Scottish Parliament election and finally declaring that there would be no second referendum in the early years of a Labour Government ${ }^{3}$. This provided Boris Johnson with an opportunity to argue that a Corbyn government would be dependent on SNP support and that the country was facing a Corbyn-Sturgeon "alliance" that planned to hold two referendums: one on Brexit and the other on Scottish independence. This was in fact a rehash of an argument David Cameron used successfully in 2015 as he warned of a Miliband-Salmond alliance. The argument reflected an assumption that Labour 
could not win an outright majority and appealed to latent anti-Scottish sentiment among English voters uncomfortable at the idea of Scotland having an undue influence on UK policy ${ }^{4}$.

12 These missteps also played into the hands of the Scottish Conservative campaign which, as in 2016 and 2017, focused on the constitutional issue. The Scottish Conservatives had been provided evidence that they should run their campaigns as a "Unionist" party rather than attempt to run on bread and butter issues as early as October 2015, when a Populus data-analyst, James Kanagasooriam, presented his findings on a pattern that allowed him to devise two new measures to describe and analyse mathematically how people voted. These measures were broadly defined as 'security' - a concept including levels of affluence, education and employment - and 'diversity' - including politics of identity and measurements of how urban an area is. According to these two measures, he discovered a latent line which separated wealthier, more secure and less diverse Conservative voters from less affluent, less secure but more diverse and urban Labour supporters. All voters and places on or close to the line were to be considered as floating voters or marginal constituencies. Crucially, Kanagasooriam's analysis of the results of the 2014 independence referendum showed that 'temperamentally Conservative voters' overlapped with large numbers of No voters who backed the Union while Labour and the SNP were in a turf war for the same voters due to a demographic overlap 5 . In contrast to Labour's ambiguous and conflicting signals on Scotland's constitutional issue, the former Scottish Conservative leader, Ruth Davidson, therefore presented a clear unionist platform which fully acknowledged the new divide in Scottish politics in the aftermath of the referendum. The 2017 general election marked a resurgence of the Conservative party in Scotland as it unexpectedly increased its share of the vote by $13.7 \%$ and gained 12 seats, all of which from the SNP and in constituencies which had voted Remain. This was evidence that the strategy worked and that it should be pursued further.

While they endorsed their leader's position over Brexit, the Scottish Conservatives therefore chose to run their 2019 campaign entirely based on their opposition to a second independence referendum and issued an electoral manifesto aptly entitled "No to Indyref2". Their main pledge was to "stop Nicola Sturgeon's plan for a second independence referendum next year", thereby attempting to thwart the SNP's own campaign, centred on a demand for a second independence referendum. The Conservatives' firm opposition to a second referendum became the leitmotiv of their campaign and, in this sense, served as a perfect negative of the SNP campaign. While the Conservative campaign attacked the idea of a second independence referendum and backed Brexit, the SNP campaign strongly opposed Brexit and advocated a second independence referendum.

14 This adversarial, polarised battle left little breathing space for Labour and the LiberalDemocrats who, caught in the middle, struggled to advance their policy agendas and more nuanced constitutional positions. Both parties supported a federal position on the constitution in the 2019 campaign but, with the Scottish electorate split in the middle over independence, they have little chance of advancing their electoral prospects so long as the constitutional issue remains prevalent in the Scottish political debate. In many respects, the last two general election campaigns in Scotland have illustrated James Mitchell's idea that "Scottish electoral politics is often defined by what parties oppose" ${ }^{16}$. The constitutional issue has been an unambiguous asset in a multi-party 
system for both the SNP and the Conservatives since the independence referendum of 2014. While the SNP has no competitor for the independence vote - the proindependence Scottish Green party remaining a fringe party able to pick up enough regional votes to give it seats in the Scottish Parliament but not enough to win constituencies under the first-past-the-post system -, the Conservatives were provided the opportunity to outbid Labour and the Liberal Democrats as the party most hostile to the SNP and independence.

15 Crucially, the constitutional issue in Scotland also allowed the Scottish Tories to avoid having to defend their government's record at Westminster by deflating attention paid to cuts in public services and the impact of austerity policies under Conservative governments but brandishing instead the threat of an economically depressed independent Scotland. Similar to that of the other UK parties, many of the pledges in the 2019 general election manifesto issued by the Scottish Conservatives related in fact to devolved issues. One of the oddities of general elections in Scotland is indeed that much of the political debate preceding the election and the contents of the manifestos issued by the parties are of little concern to Scotland as they fall under the remit of the Scottish Parliament. Many of the controversies raised during the 2019 campaign that were related to health issues, the construction of new hospitals, private schools, household bills and housing were in fact devolved issues and did not directly concern the Scottish electorate. To introduce the policies contained in their manifesto, the Scottish Conservatives would have to win the support of the SNP government - which would appear unlikely - or win the next Holyrood election - which is as unlikely. This shields the party from defending its more controversial manifesto pledges as it can always argue that they do not concern Scotland and deflates attention from the detail of its proposed manifesto policies, enabling it to concentrate instead on its defence of the Union.

16 The Tories also now benefit from the belief in some parts of Scotland that the SNP under Sturgeon has become more of a "central belt party". Their focus during the campaign therefore turned to many of the north-east constituencies which they prised from the SNP in 2017 and which coincidentally contain more pro-Brexit voters than other constituencies in Scotland. Parts of the 2019 Scottish Conservative manifesto was thus veered towards those communities, whose livelihoods are often linked to the fishing, oil and gas sectors. One of the pledges of the Scottish Conservative manifesto for instance was to bring an oil and gas sector deal to support the North East economy and protect the 100,000 jobs in Scotland that rely on oil and gas. Similarly, the Scottish Conservative manifesto pledged to take back control of the UK's fisheries by becoming an independent coastal state, maintain funding for fisheries throughout the Parliament and support regeneration of coastal communities and introduce a legal commitment to fish sustainably. These fishing communities, to whom the Conservatives promised a "sea of opportunity", have overall tended to vote Leave in higher numbers and were thus also more likely to favour the only major party in Scotland claiming to represent the Leave minority. The Tories were able to combine a strong anti-independence message while harnessing the minority Leave vote. Unsurprisingly, they fared well in the north-eastern constituencies of Banff and Buchan (deemed to be the only constituency that voted Leave in Scotland with $54 \%$ of the vote), Moray (which held 49.9\% Leavers to $50.1 \%$ Remainers), and Aberdeenshire West \& Kincardine (61.5\% 
Remainers to $38.5 \%$ Leavers) where they held on to their seats. They came a close second to the SNP in Gordon and, to a lesser degree, in Angus and Aberdeen South.

\section{The SNP, Brexit and Indyref2}

17 The results of the European referendum of 2016 gave the SNP a chance to reboot their independence campaign by claiming that the circumstances of the 2014 independence referendum had changed and that Scots should be given a new opportunity to choose their constitutional future. The SNP's 2016 Scottish Parliament election manifesto provided for the eventuality of a second independence referendum after a Brexit vote as it stated that a new referendum would be held only "if there is clear and sustained evidence that independence has become the preferred option of a majority of the Scottish people - or if there is a significant and material change in the circumstances that prevailed in 2014, such as Scotland being taken out of the EU against our will" . The discrepancy between the results of the EU referendum in Scotland (with 62\% voting Remain and 38\% voting Leave) and in the rest of Britain did correspond to the change of circumstances foreseen by the 2016 manifesto upon which the current SNP government was elected. However, there was little appetite for a second referendum in 2017 and the surge in support for independence which the Nationalists expected after the European referendum failed to materialise. The SNP lost 21 seats in 2017 and $13.1 \%$ of the vote with some safe seats such as those of former leader Alex Salmond or Deputy leader Angus Robertson falling to the hands of the Scottish Conservatives. Interpreting the results as a clear sign that the Scottish electorate rejected her plans for a second independence referendum, Scotland's First Minister Nicola Sturgeon backtracked on her promises and temporarily shelved her plans for a second referendum.

However, the rise in support for independence witnessed by several opinion polls since the spring of 2019, encouraged the SNP to campaign on an independence referendum platform once again in December 2019. Indeed, several polls consistently registered higher levels of support for independence, putting the percentage of people in favour of independence at an average of $49 \%$ and making it a much more likely scenario. On average, the five polls published during the 2019 campaign appeared to confirm this trend and put support for independence at $48 \%$, that is 1 point below the polls published previously but still 4 points more than the results of the 2014 referendum. This trend was confirmed by the three polls published for Brexit Day on $31^{\text {st }}$ January (YouGov, Survation and Panelbase) which put support for independence at an average of $51 \%$. Polls later published in the spring of 2020 recorded a slight fall back to $49 \%$ but confirmed that support for independence remained higher than it had before.

Furthermore, the increase of support for independence in the 2019 polls appeared to have occurred primarily among Remain voters: a 55\% support for independence among Remain voters was 5 points higher than it was the previous year. Meanwhile, support for independence among Leave voters dropped from $34 \%$ to $30 \%$. The Brexit Day polls further confirmed these trends, reporting an increase of support for independence of an average 2 points with Remain voters and an average drop of 1.5 points with Leave voters. ${ }^{7}$ This suggested that the Conservative governments' chaotic handling of Brexit eroded support for the Union among Remain voters and that the SNP could potentially tap into the majority of Remain voters in Scotland to support them in December 2019. This, of course, was to the advantage of the Nationalists who could rely on a pool of 
voters twice as large as that of Leave voters which the Scottish Conservatives were vying to attract. While Labour is the main recipient of the Remain vote south of the border, this position is held by the SNP in Scotland.

Besides, detailed analysis of YouGov's Brexit Day poll shows that while hardly anyone who voted No and Leave have changed their minds about independence, one in five (21\%) of those who voted No in 2014 and Remain in 2016 now say they would vote Yes, and as many as three in ten (30\%) who voted Yes and Leave now say they would vote $\mathrm{No}^{8}$. These trends therefore represented a great advantage to the Nationalists in the 2019 general election. Their potential repercussions on Scottish political parties will be great if confirmed as they could ensure the continuing hegemony of the SNP as the sole major party campaigning on a pro-independence pro-European platform. Indeed, given the way Brexit has affected support for independence, the three main unionist parties in Scotland now appear to be fighting over a much more limited pool of voters: the number of people who voted Yes and Leave (11\%) is much lower than the number of people who voted No and Remain (29\%).

21 If anything, the 2019 general election results suggest that the future prospects of the SNP in the 2021 Scottish Parliament elections appear all the brighter as the link between party support and Brexit vote has strengthened between 2017 and 2019. While the Scottish Conservatives consolidated their support among Leave voters $(+1 \%)$, they lost $6 \%$ of votes among Remain voters. On the other hand, the results of the British Election Panel Study show an increase in support for the SNP among both Remain (+9\%) and Leave voters $(+3 \%)$ in 2019 compared to 2017. Findings from the study nevertheless suggest the SNP also benefited from a greater increase in support among voters who had voted No to independence in $2014(+10 \%)$ than among voters who had voted Yes $(+4 \%)$, thereby indicating that No voters decided to switch their support to the SNP despite its independence stance and because of its clear position over EU membership. The Scottish Conservatives in turn lost $8 \%$ of their support among No voters. Indeed, Brexit, rather than support for independence, appears to have been key to the SNP's success in the 2019 general election.

\begin{tabular}{|l|l|l|l|l|l|l|}
\hline 2016 EU Referendum vote & 2017 & & 2019 & & $2019-2017$ & \\
\hline & Remain & Leave & Remain & Leave & Remain & Leave \\
\hline Conservative & $18 \%$ & $49 \%$ & $12 \%$ & $50 \%$ & -6 & +1 \\
\hline Labour & $29 \%$ & $22 \%$ & $21 \%$ & $14 \%$ & -8 & -8 \\
\hline Lib Dem & $9 \%$ & $4 \%$ & $13 \%$ & $5 \%$ & +4 & +1 \\
\hline SNP & $43 \%$ & $24 \%$ & $52 \%$ & $27 \%$ & +9 & +3 \\
\hline 2014 Independence referendum vote & Yes & No & Yes & No & Yes & No \\
\hline Conservative & $9 \%$ & $47 \%$ & $9 \%$ & $39 \%$ & 0 & -8 \\
\hline Labour & $17 \%$ & $34 \%$ & $11 \%$ & $25 \%$ & -6 & -9 \\
\hline Lib Dem & $2 \%$ & $10 \%$ & $3 \%$ & $15 \%$ & +1 & +5 \\
\hline
\end{tabular}




\begin{tabular}{|l|l|l|l|l|l|l|}
\hline SNP & $72 \%$ & $9 \%$ & $76 \%$ & $19 \%$ & +4 & +10 \\
\hline
\end{tabular}

\section{Conclusion}

Speaking ahead of an independence rally in George Square on $2^{\text {nd }}$ November 2019, Nicola Sturgeon declared "This election is Scotland's chance to escape Brexit and to put our future into our own hands", thus setting the tone for the SNP's campaign. She described her party as "Scotland's Remain party" and denounced both the Conservatives' "Brexit obsession" and Labour's "woeful lack of leadership". Having won 48 seats in Parliament and interpreting her majority as a renewed mandate, First Minister Nicola Sturgeon wrote to Boris Johnson on $19^{\text {th }}$ December to request the powers to legally stage another referendum under section 30 of the 1998 Scotland Act. She further called for the Scottish Parliament to be granted permanent powers to hold subsequent referendums on independence from the UK in a 38-page document entitled "Scotland's Right to Choose". The negative answer she received on $14^{\text {th }}$ January 2020 had been anticipated by the First Minister, who would undoubtedly prefer support for independence to continue rising well above the 50\% threshold needed for Scotland to obtain its independence. The Nationalists will vie for a majority in the 2021 Scottish Parliament election as a platform towards a second independence referendum and the UK government's management of Brexit and the coronavirus pandemic may shift opinions further. If the 2017 general election results suggested that Scots were in no mood for a second independence referendum, the 2019 general election has shown substantial changes in attitudes to independence and Brexit. A May 2020 Ipsos Mori poll for BBC Scotland found majority support for a second referendum with $63 \%$ of respondents saying they now wanted another independence referendum within the next five years. If anything, the results of the 2019 general election in Scotland therefore served as a stark reminder of the strains that leaving the European Union is putting on the future of the UK Union.

Fiona Simpkins is a Senior Lecturer in Contemporary British History, Politics and Society at the University Lumière of Lyon, France. Her main areas of research are devolution, Scottish politics, nationalism and the constitutional debate in Scotland. She has published her research in a variety of books and journals, including the Revue Française de Civilisation Britannique, Observatoire de la Société Britannique, and Etudes Ecossaises.

\section{BIBLIOGRAPHY}

Brooks, Libby, "Dugdale : UK must allow Scottish independence vote if people want it", Guardian, $7^{\text {th }}$ July 2016; 
Curtice, John, "Brexit Day polls show increased support for Yes", What Scotland Thinks, $7^{\text {th }}$ February 2020, www.whatscotlandthinks.org, last accessed $1^{\text {st }}$ June 2020.

Curtice, John, "Brexit or Indyref2? The Foundations of the SNP's electoral advance", What Scotland Thinks, 19th December 2019, www.whatscotlandthinks.org, last accessed $1^{\text {st }}$ June 2020.

Henderson et al. "Scottish Labour as a case study in party failure: evidence from the 2019 UK general election in Scotland”, Scottish Affairs, 29.2, 2020, pp. 127-140

Johnson, Simon, “Jeremy Corbyn in 'complete disarray' over second independence referendum during Scottish election tour", The Telegraph, 13 $3^{\text {th }}$ November 2019.

Mitchell, James, “General election 2019: a different contest in Scotland”, Democratic Audit UK, democraticaudit.com, last accessed $10^{\text {th }}$ March 2020.

Riddell, Mary, “The long road: interview with Kezia Dugdale”, Fabian Review, $1^{\text {st }}$ April 2016, www.fabians.org.uk, last accessed $1^{\text {st }}$ June 2020.

Shipman, Tim, Fall Out. A Year of Political Mayhem (2018), London: William Collins.

Sparrow, Andrew, “General election: Boris Johnson urges voters to reject 'Sturgeon- Corbyn alliance", Guardian, $13^{\text {th }}$ November 2019.

\section{NOTES}

1. Henderson et al. "Scottish Labour as a case study in party failure: evidence from the 2019 UK general election in Scotland", Scottish Affairs, 29.2, 2020, pp. 127-140

2. Libby Brooks, "Dugdale: UK must allow Scottish independence vote if people want it", Guardian, $7^{\text {th }}$ July 2016; Mary Riddell, “The long road", Fabian Review, $1^{\text {st }}$ April 2016, www.fabians.org.uk, last accessed $1^{\text {st }}$ June 2020.

3. Simon Johnson, "Jeremy Corbyn in 'complete disarray' over second independence referendum during Scottish election tour", The Telegraph, 13 $3^{\text {th }}$ November 2019.

4. Andrew Sparrow, "General election: Boris Johnson urges voters to reject 'Sturgeon- Corbyn alliance", Guardian, $13^{\text {th }}$ November 2019.

5. Tim Shipman, Fall Out. A Year of Political Mayhem (2018), London: William Collins.

6. James Mitchell, "General election 2019: a different contest in Scotland", Democratic Audit UK, democraticaudit.com, last accessed $10^{\text {th }}$ March 2020.

7. John Curtice, "Brexit or Indyref2? The Foundations of the SNP's electoral advance", What Scotland Thinks, 19th December 2019, www.whatscotlandthinks.org, last accessed $1^{\text {st }}$ June 2020.

8. John Curtice, "Brexit Day polls show increased support for Yes", What Scotland Thinks, $7^{\text {th }}$ February 2020, www.whatscotlandthinks.org, last accessed $1^{\text {st }}$ June 2020.

\section{ABSTRACTS}

While " getting Brexit done" featured at the heart of the UK Conservative 2019 general election campaign, it was clear that a similar strategy was never going to function in Scotland where $62 \%$ voted Remain in 2016. Neither could the Conservatives afford to ignore Scotland as they knew too 
well that they had only managed to snatch victory out of the jaws of defeat in the 2017 general election thanks to the crucial addition of thirteen Scottish Conservative seats. The upsurge in Conservative votes in Scotland coincided with a strong unionist message which had proved fruitful in the 2017 general election despite a political context dominated by Brexit. Could the Scottish Conservatives repeat their success of 2017 by focusing on the Union and betting that Scotland's constitutional debate would once again trump the issue of Brexit? This paper will seek to compare the last two general election campaigns in Scotland in order to determine to what extent Brexit determined the results of the 2019 general election.

Si mettre en œuvre le Brexit était au cœur de la campagne des conservateurs lors des élections législatives britanniques de 2019, il apparaissait clairement que cette stratégie ne fonctionnerait pas en Ecosse où $62 \%$ de l'électorat s'était prononcé en faveur du maintien du Royaume-Uni au sein de l'Union Européenne en 2016. Les conservateurs ne pouvaient non plus se permettre d'ignorer l'Ecosse dont les treize sièges conservateurs écossais leur avait permis de justesse de se maintenir à la tête du gouvernement britannique à la suite des élections législatives de 2017. La résurgence du vote conservateur en Ecosse tenait à une forte campagne unioniste qui avait porté ses fruits en 2017 malgré un contexte politique dominé par le Brexit. Les conservateurs pourraient-ils de nouveau l'emporter en focalisant leur campagne sur l'Union britannique et en pariant que la question constitutionnelle écossaise éclipserait celle du Brexit? Cet article propose de comparer les deux dernières campagnes législatives britanniques en Ecosse afin de déterminer l'influence du Brexit sur les résultats des élections de décembre 2019.

\section{INDEX}

Mots-clés: Brexit, élections législatives britanniques 2019, référendum sur l'indépendance de l'Ecosse, SNP, Parti conservateur écossais, Parti travailliste écossais

Keywords: Brexit, general election 2019, Scottish independence referendum, SNP, Scottish Conservative Party, Scottish Labour Party

\section{AUTHOR}

\section{FIONA SIMPKINS}

Université Lumière, Lyon 